\title{
The Clinical Impact of Tumor Grade Heterogeneity in Non- muscle-invasive Urothelial Carcinoma of the Bladder
}

\section{Kasa Invaze Olmayan Ürotelyal Mesane Kanserinde Tümör Grade Heterojenitesinin Klinik Önemi}

\author{
(D) Meftun CULPAN1, (D) Ferhat KESER', (D) Ayberk IPLIKCII, (D) Gozde KIR2, (D) Gokhan ATIS1, (1) Asif YILDIRIM1
}

IIstanbul Medeniyet University Faculty of Medicine, Department of Urology, Istanbul, Turkey

2Istanbul Medeniyet University Faculty of Medicine, Department of Pathology, Istanbul, Turkey

\begin{abstract}
Objective: This study aimed to determine the oncological outcomes of mixed-grade tumors by comparing them with pure low-grade and high-grade tumors.

Methods: We retrospectively reviewed the medical records of patients with primary non-muscle-invasive bladder cancer. Patients were categorized into three groups according to the histological grade of their tumors: low-grade, mixed-grade, and high-grade. Clinicopathological characteristics and oncological outcomes, such as recurrence-free survival (RFS), progression-free survival (PFS), and cancer-specific survival (CSS), were compared between the three groups.

Results: A total of 369 patients (190 low, 40 mixed, and 139 high-grade) were included in our study, with a mean follow-up of $55.94 \pm 41.73$ months. Patients with mixed-grade tumors had lower rates of pT1 stage diseases than those with high-grade tumors $(42.5 \%$ vs. $64.0 \%$, respectively) and higher rates than those with low-grade tumors ( $14.7 \%$ vs. $42.5 \%$, respectively) ( $\mathrm{p}=0.001)$. There was no significant difference in RFS between low-, mixed-, and high-grade tumor patients $(\mathrm{p}=0.887)$. Patients with mixed-grade tumors had worse PFS and CSS outcomes than those with low-grade tumors $(199.84 \pm 23.22$ vs. $214.94 \pm 15.92$ for PFS and $202.07 \pm 19.86$ vs. $233.61 \pm 9.84$ for CSS, respectively) and better PFS and CSS outcomes than those with highgrade tumors $(199.84 \pm 23.22$ vs. $163.28 \pm 16.18$ for PFS and $202.07 \pm 19.86$ vs. $180.81 \pm 15.89$ for CSS, respectively). although these comparisons were not statistically significant.

Conclusions: Patients with mixed-grade tumors had worse PFS and CSS outcomes than patients with low-grade tumors and better PFS and CSS outcomes than patients with high-grade tumors, although these comparisons were not statistically significant. Our results should be verified by future studies.

Keywords: Bladder cancer, heterogeneity, histologic grade, progression, recurrence
\end{abstract}

\section{Öz}

Amaç: Çalıșmamızda histolojik olarak düşük ve yüksek derecenin bir arada olduğu karma dereceli tümörlerin onkolojik sonuçlarının saf düşük dereceli ve yüksek dereceli tümörler ile karşılaştırılması amaçlandı.

Yöntemler: Primer kasa invaze olmayan mesane kanserli hastaların tıbbi kayıtlarını geriye dönük olarak inceledik. Hastalar histolojik dereceye göre düşük, karma ve yüksek dereceli olmak üzere üç gruba ayrıldı. Üç grubun nükssüz sağkalım (NS), progresyonsuz sağkalım (PS) ve kansere özgü sağkalım (KSS) gibi onkolojik sonuçları ve klinikopatolojik özellikleri karşılaştıııldı.

Bulgular: Ortalama 55,94ะ41,73 aylık takipte toplam 369 hasta (190 düşük, 40 karma ve 139 yüksek dereceli) çalışmamıza dahil edildi. pT1 evre hastalık oranı; karma dereceli tümörü olan hastalarda yüksek dereceli

Cite as: Culpan M, Keser F, Iplikci A, Kir G, Atis G, Yildirim A. The Clinical Impact of Tumor Grade Heterogeneity in Non-muscle-invasive Urothelial Carcinoma of the Bladder. Medeni Med J 2021;36:310-317

${ }^{\circledR}$ Copyright 2021 by the Istanbul Medeniyet University / Medeniyet Medical Journal published by Galenos Publishing House. Licenced by Creative Commons Attribution-NonCommercial 4.0 International (CC BY-NC 4.0) 
tümörlere göre daha düşük oranda (sırasıyla \%42,5 ve \%64,0) ve düşük dereceli tümörlere göre daha yüksek oranda (sırasıyla \%42,5 ve \%14,7) gözlendi $(\mathrm{p}=0,001)$. Düşük, karma ve yüksek dereceli hastalar arasında NS açısından istatistiksel olarak anlamlı bir fark yoktu ( $\mathrm{p}=0,887)$. Karma dereceli tümörü olan

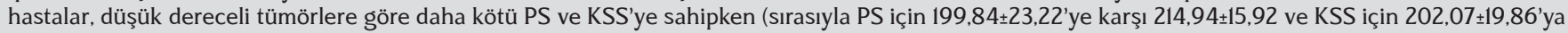

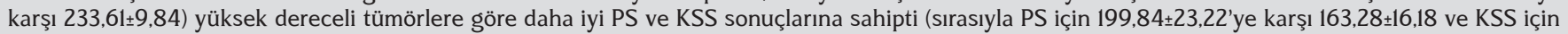

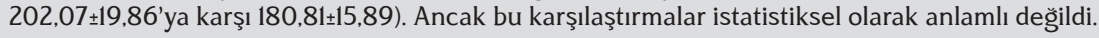

Sonuçlar: Karma dereceli tümörü olan hastalarda, düşük dereceli tümörlere göre daha kötü PS ve KSS saptanırken, yüksek dereceli tümörlere göre daha iyi PS ve KSS saptandı. Ancak bu karşılaştırmalar istatistiksel olarak anlamlı değildi. Sonuçlarımız gelecek çalışmalarla doğrulanmalıdır.

Anahtar kelimeler: Mesane kanseri, heterojenite, histolojik derece, progresyon, nüks

\section{INTRODUCTION}

Urothelial carcinoma of the bladder (UCB) is among the most common malignancies, especially in men, with 64,280 estimated new cases in 2021 in the USA! Approximately $75 \%$ of patients with UCB have a nonmuscle-invasive disease at first presentation. However, progression rates of these patients differ from $3.7 \%$ to $53 \%$ at 10 years follow-up, based on clinical and pathological characteristics ${ }^{2.3}$. Histological grade is a well-known predictor of stage progression and is determined by the degree of nuclear anaplasia and mitotic activity ${ }^{4}$.

Histological grading of UCB remains controversial as a result of two different classification systems and interobserver variability ${ }^{4}$. The World Health Organization (WHO) 1973 grading system was replaced by the WHO 2004 grading system; however, some guidelines still suggest the use of both grading systems ${ }^{5,6}$. The WHO 2004 grading system has three categories: papillary urothelial neoplasm of low malignant potential (PUNLMP), low-grade, and high-grade 5 . In this classification system, tumor grade heterogeneity is ignored and tumors are classified according to the highest grade regardless of the low percentage of high-grade components in extensive low-grade tumors.

In these circumstances, patients with mixed-grade UCB are treated as patients with high-grade tumors. However, in literature, some studies claim that the prognosis of mixed-grade tumors is closer to that of lowgrade tumors rather than high-grade tumors ${ }^{7}$. Therefore, controversies regarding tumor heterogeneity persist. This study aimed to determine the oncological outcomes of mixed-grade tumors by comparing them with pure lowgrade and high-grade tumors.

\section{MATERIALS and METHODS}

Following approval by the review board of Istanbul Medeniyet University Goztepe Training and Research
Hospital (decision no: 2021/0280, date: 26.05.2021), we retrospectively reviewed the medical records of patients who had undergone a primary transurethral resection of a bladder tumor (TUR-BT) from January 2010 to January 2021. In this study, we included patients with nonmuscle-invasive bladder cancer (NMIBC) (pTa-pT1) who had at least 12 months of follow-up. We excluded patients with muscle-invasive bladder cancer, previous bladder cancer history, concomitant carcinoma in situ, PUNLMP, incomplete resection, variant histology, or missing clinicopathologic data. Data regarding patients' age, gender, body mass index, smoking history, comorbidities, symptoms before TUR-BT, number of tumors, tumor diameter, $\mathrm{T}$ stage, histologic grade, and adjuvant intravesical Bacillus Calmette-Guérin (BCG) treatments were recorded.

After complete TUR-BT, pathological specimens were evaluated by experienced uropathologists according to the tumor, node, and metastasis classification of stage and 2004/2016 WHO histological grading system ${ }^{5,8}$ in a single institution. Tumors containing $\geq 25 \%$ high-grade components were accepted as high-grade, while tumors with pure low-grade areas were accepted as low-grade. In addition, tumors having both low and high-grade within the same lesion, but $<25 \%$ high-grade areas, were accepted as mixed-grade (Figure 1).

After the complete initial TUR-BT, most patients with pT1 tumors and pTa high-grade tumors underwent a second resection. Afterward, intravesical BCG treatment was recommended to patients with high-risk diseases according to European Association of Urology (EAU) guidelines. Patients' follow-up were performed with cystoscopy and urine cytology according to patients' risk groups, as indicated by EAU NMIBC guidelines ${ }^{6}$. Detection of a pathologically confirmed tumor during follow-up was defined as recurrence, whereas detection of a pT2 tumor in patients with tumor recurrence was defined as progression. 


\section{Statistical Analysis}

Statistical analysis was performed with the number cruncher statistical system. Compliance of the variables with the normal distribution was determined by ShapiroWilk or Kolmogorov-Smirnov tests. Descriptive statistics (mean, standard deviation, median, minimum-maximum frequency, and percentage) were given. For normally distributed variables, One-Way ANOVA was used for the comparisons of more than two groups, whereas Student's t-test was used for the comparisons of two groups. The chi-square test was used to compare categorical variables. Kaplan-Meier analysis and the Log Rank test were used for survival analysis. Significance was evaluated at the $\mathrm{p}<0.05$ level.

\section{RESULTS}

A total of 369 patients were included in our study, with a mean follow-up of $55.94 \pm 41.73$ months. The mean age of the patients was $64.67 \pm 10.85$ years, and $84.3 \%$ (311) of the patients were male. In histological grade analysis, 190 (51.5\%) patients had low-grade tumors, 40 (10.8\%) patients had mixed-grade tumors, and 139 (37.7\%) patients had high-grade tumors. The clinicopathological characteristics of the patients were compared according to the histological grade, as presented in Table 1. Patients with high-grade tumors were significantly older than patients with low and mixed-grade tumors $(\mathrm{p}=0.014)$. The rate of multiple tumors and tumors with a diameter $\geq 3$ $\mathrm{cm}$ was higher in patients with mixed and high-grade tumors than patients with low-grade tumors ( $\mathrm{p}=0.001$ and $\mathrm{p}=0.001$, respectively). Patients with mixed-grade tumors had lower rates of pT1 stage diseases than those with high-grade tumors $(42.5 \%$ vs. $64.0 \%$, respectively) and higher rates of $\mathrm{pT1}$ diseases than those with low-grade tumors ( $42.5 \%$ vs. $14.7 \%$, respectively) ( $\mathrm{p}=0.001$ ).

Tumor recurrence was observed in 190 (51.5\%) patients and the mean recurrence-free survival (RFS) was $57.40 \pm 5.92$ months. The comparison of patients with and without recurrence in the follow-up period is presented in Table 2. Patients with recurrence had a higher rate

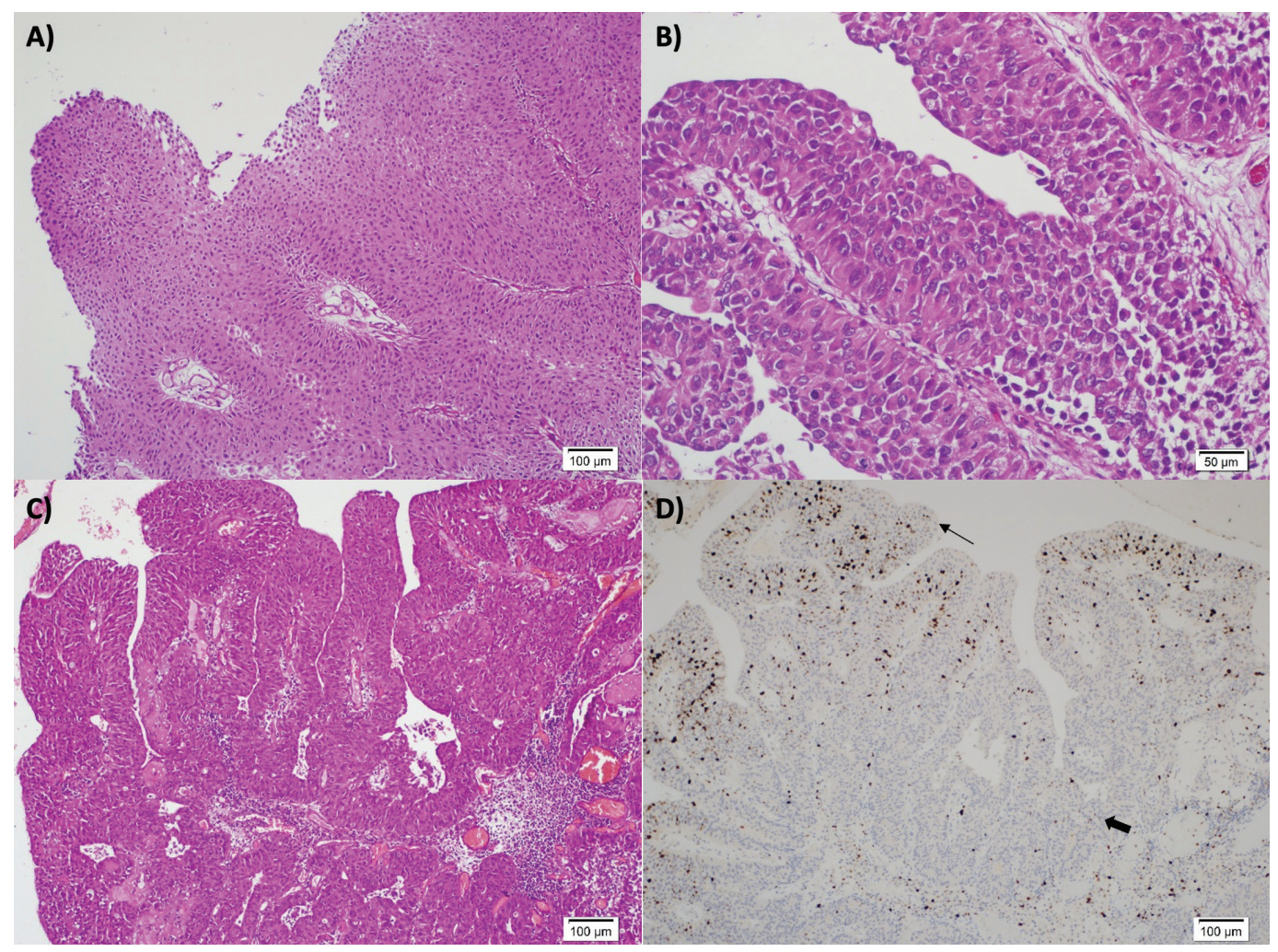

Figure 1. A) Low-grade papillary urothelial carcinomas display minimal cytologic and architectural atypia [Haematoxylin and eosin (HCE) ×100]. B) High-grade papillary urothelial carcinomas display marked cytologic and architectural atypia. The neoplastic cells are arranged haphazardly with the loss of polarity. Mitotic activity is increased (H\&E $\times 200)$. C) Papillary urothelial carcinoma with both low and high-grade areas (H\&E $\times 40)$. D) Ki-67 proliferation index was higher in the highgrade areas (thin arrow) than in the low-grade areas (thick arrow) $(\mathrm{Ki}-67 \times 40)$. 
of symptoms prior to initial TUR-BT, higher T stage, and lower rates of adjuvant intravesical BCG treatment than patients without recurrence $(\mathrm{p}=0.009, \mathrm{p}=0.006$, and $\mathrm{p}=0.001$, respectively). Tumor progression was detected in $30(8.1 \%)$ patients and the mean progression-free survival (PFS) was 202.68 \pm 10.56 months. The comparison of patients with and without progression is presented in Table 3. Patients with high-grade tumors and patients with $\mathrm{T1}$ tumors had higher rates of progression $(\mathrm{p}=0.026$ and $\mathrm{p}=0.001$, respectively).

According to the histological grade in oncological survival analysis, there was no statistically significant difference between low, mixed, and high-grade patients in terms of RFS ( $\mathrm{p}=0.887$ ) (Figure 2A). According to the histological grade in Log-rank analysis, there was a statistically significant difference between the groups in terms of PFS ( $\mathrm{p}=0.008)$. Patients with high-grade tumors significantly had worse PFS (Figure 2B). However, there was no statistically significant difference between patients with low-grade and mixed-grade tumors $(\mathrm{p}=0.627)$ and between the groups with mixed-grade and high-grade tumors ( $p=0.197$ ). In the cancer-specific survival (CSS) analysis, there was a statistically significant difference between the histological groups $(p=0.021)$. The CSS of patients with high-grade tumors was significantly lower than that of patients with low-grade tumors (Figure 2C). However, there was no statistically significant difference between the CSS of patients with low-grade tumors and that of patients with mixed-grade tumors ( $p=0.156$ ). Similarly, there was no statistically significant difference between the CSS of patients with mixed-grade tumors and that of patients with high-grade tumors ( $\mathrm{p}=0.621$ ).

\section{DISCUSSION}

To date, the oncological effects of focal high-grade areas in extensive low-grade tumors have not been investigated extensively. Tumor heterogeneity in UCB was first evaluated in 2000 by Cheng et al. ${ }^{9}$. They classified

\begin{tabular}{|c|c|c|c|c|c|}
\hline & & \multicolumn{3}{|c|}{ Tumor grade } & \multirow{2}{*}{$p$ value } \\
\hline & & Low $(n=190)$ & Mixed $(n=40)$ & High (n=139) & \\
\hline \multirow{2}{*}{ Age (year) } & Mean \pm SD & $63.37 \pm 11.14$ & $63.5 \pm 10.04$ & $66.79 \pm 10.42$ & a $0.014^{*}$ \\
\hline & Median (min-max) & $63.5(33-101)$ & $65(43-78)$ & $67(33-90)$ & \\
\hline \multirow{2}{*}{ Gender, n (\%) } & Male & $158(83.2)$ & $33(82.5)$ & $120(86.3)$ & ' 0.699 \\
\hline & Female & $32(16.8)$ & $7(17.5)$ & $13(13.7)$ & \\
\hline \multirow{2}{*}{ BMI, $\left(\mathbf{k g} / \mathbf{m}^{2}\right)$} & Mean \pm SD & $27.46 \pm 4.29$ & $27.14 \pm 4.2$ & $27.09 \pm 4.79$ & a 0.736 \\
\hline & Median (min-max) & $27.1(17.9-42.4)$ & $27.1(19.2-35.9)$ & $26.2(15.4-44.9)$ & \\
\hline \multirow{3}{*}{$\begin{array}{l}\text { Smoking history, } \\
\text { n (\%) }\end{array}$} & No & $34(17.9)$ & $3(7.5)$ & $23(16.5)$ & b0.560 \\
\hline & Ex-smoker & 89 (46.8) & $23(57.5)$ & $68(48.9)$ & \\
\hline & Smoker & $67(35.3)$ & $14(35.0)$ & $48(34.5)$ & \\
\hline \multirow{2}{*}{ CCI } & Mean \pm SD & $4.97 \pm 1.69$ & $4.65 \pm 1.66$ & $5.17 \pm 1.78$ & ${ }^{\mathrm{a}} 0.217$ \\
\hline & Median (min-max) & $5(1-10)$ & $5(2-8)$ & $5(0-11)$ & \\
\hline \multirow{3}{*}{ Symptom, n (\%) } & Asymptomatic & $22(11.6)$ & $2(5.0)$ & $6(4.3)$ & b0.261 \\
\hline & Macrohematuria & $152(80)$ & $34(85.0)$ & $119(85.6)$ & \\
\hline & LUTS & $16(8.4)$ & $4(10.0)$ & $14(10.1)$ & \\
\hline \multirow{2}{*}{$\begin{array}{l}\text { Number of tumors, } \\
\text { n (\%) }\end{array}$} & Single & $122(64.2)$ & $18(45.0)$ & $58(41.7)$ & ${ }^{\mathrm{b}} 0.001^{* \star}$ \\
\hline & Multiple & $68(35.8)$ & $22(55.0)$ & $81(58.3)$ & \\
\hline \multirow{2}{*}{$\begin{array}{l}\text { Tumor diameter n } \\
(\%)\end{array}$} & $<3 \mathrm{~cm}$ & $110(57.9)$ & $11(27.5)$ & $47(33.8)$ & ${ }^{\mathrm{b}} 0.001^{* \star}$ \\
\hline & $\geq 3 \mathrm{~cm}$ & $80(42.1)$ & $29(72.5)$ & $92(66.2)$ & \\
\hline \multirow{2}{*}{ T stage, n (\%) } & Ta & $162(85.3)$ & $23(57.5)$ & $50(36.0)$ & ${ }^{\mathrm{b}} 0.001^{\star \star}$ \\
\hline & $\mathrm{T} 1$ & $28(14.7)$ & $17(42.5)$ & $89(64.0)$ & \\
\hline \multirow{2}{*}{$\begin{array}{l}\text { Intravesical BCG, n } \\
(\%)\end{array}$} & BCG (-) & $178(93.7)$ & $16(40.0)$ & $54(38.8)$ & ${ }^{\mathrm{b}} 0.001^{\star \star}$ \\
\hline & BCG $\left(^{+}\right)$ & $12(6.3)$ & $24(60.0)$ & 85 (61.2) & \\
\hline
\end{tabular}



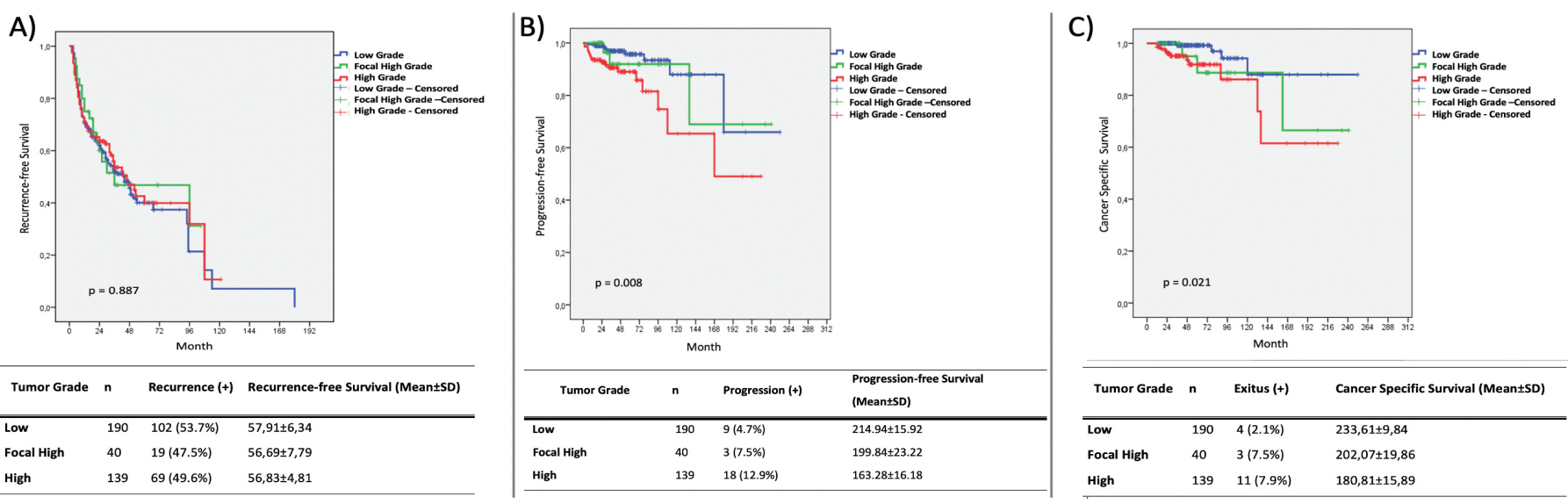

Figure 2. Kaplan-Meier survival analysis of patients with low-grade, mixed-grade, and high-grade tumors. A) Recurrencefree survival, B) Progression-free survival, C) Cancer-specific survival.

\begin{tabular}{|c|c|c|c|c|}
\hline & & \multicolumn{2}{|c|}{ Recurrence } & \multirow{2}{*}{ p value } \\
\hline & & $(-)$ & $(+)$ & \\
\hline \multirow{2}{*}{ Age (year) } & Mean \pm SD & $65.61 \pm 10.58$ & $63.78 \pm 11.06$ & c0.106 \\
\hline & Median (min-max) & $65(33-89)$ & $64(33-101)$ & \\
\hline \multirow{2}{*}{ Gender n (\%) } & Male & $152(84.9)$ & $159(83.7)$ & b0.745 \\
\hline & Female & $27(15.1)$ & $31(16.3)$ & \\
\hline \multirow{2}{*}{ BMI $\left(\mathbf{k g} / \mathbf{m}^{2}\right)$} & Mean \pm SD & $27.29 \pm 4.08$ & $27.28 \pm 4.81$ & ${ }^{\mathrm{c}} 0.988$ \\
\hline & Median (min-max) & $27.2(18.8-42.4)$ & $26.8(15.4-44.9)$ & \\
\hline \multirow{3}{*}{$\begin{array}{l}\text { Smoking history, } \\
\text { n (\%) }\end{array}$} & No & $31(17.3)$ & $29(15.3)$ & b0.866 \\
\hline & Ex-smoker & $86(48.0)$ & 94 (49.5) & \\
\hline & Smoker & $62(34.6)$ & $67(35.3)$ & \\
\hline \multirow{2}{*}{ CCI } & Mean \pm SD & $4.98 \pm 1.6$ & $5.05 \pm 1.84$ & ${ }^{\circ} 0.699$ \\
\hline & Median (min-max) & $5(1-9)$ & $5(0-11)$ & \\
\hline \multirow{3}{*}{ Symptom, n (\%) } & Asymptomatic & $22(12.3)$ & $8(4.2)$ & ${ }^{\mathrm{b}} 0.009^{* *}$ \\
\hline & Macrohematuria & $138(77.1)$ & 167 (87.9) & \\
\hline & LUTS & 19 (10.6) & $15(7.9)$ & \\
\hline \multirow{3}{*}{ Tumor grade, n (\%) } & Low & $88(49.2)$ & $102(53.7)$ & b0.666 \\
\hline & Focal high & $21(11.17)$ & $19(10.0)$ & \\
\hline & High & $70(39.1)$ & 69 (36.3) & \\
\hline \multirow{2}{*}{$\begin{array}{l}\text { Number of tumors, } \\
\text { n (\%) }\end{array}$} & Single & 99 (55.3) & $99(52.1)$ & b0.538 \\
\hline & Multiple & $80(44.7)$ & $91(47.9)$ & \\
\hline \multirow{2}{*}{ Tumor diameter, n (\%) } & $<3 \mathrm{~cm}$ & $83(46.4)$ & $85(44.7)$ & b 0.753 \\
\hline & $\geq 3 \mathrm{~cm}$ & 96 (53.6) & $105(55.3)$ & \\
\hline \multirow{2}{*}{ T stage, n (\%) } & Ta & $128(71.5)$ & $107(56,3)$ & ${ }^{\mathrm{b}} 0.006^{* *}$ \\
\hline & $\mathrm{T} 1$ & $51(28,5)$ & $83(43,7)$ & \\
\hline \multirow{2}{*}{$\begin{array}{l}\text { Intravesical BCG, } \\
\text { n (\%) }\end{array}$} & BCG (-) & $105(58.7)$ & $143(75.3)$ & ${ }^{\mathrm{b}} 0.001^{* *}$ \\
\hline & $\mathrm{BCG}(+)$ & 74 (41.3) & $47(24.7)$ & \\
\hline
\end{tabular}




\begin{tabular}{|c|c|c|c|c|}
\hline & & \multicolumn{2}{|c|}{ Progression } & \multirow{2}{*}{$p$ value } \\
\hline & & $(-)$ & $(+)$ & \\
\hline \multirow{2}{*}{ Age (year) } & Mean \pm SD & $64.65 \pm 10.93$ & $64.9 \pm 10.09$ & c0.905 \\
\hline & Median (min-max) & $65(33-101)$ & $64.5(43-87)$ & \\
\hline \multirow{2}{*}{ Gender, n (\%) } & Male & $286(84.4)$ & $25(83.3)$ & ' 0.798 \\
\hline & Female & $53(15.6)$ & $5(16.7)$ & \\
\hline \multirow{2}{*}{ BMI $\left(\mathbf{k g} / \mathbf{m}^{2}\right)$} & Mean \pm SD & $27.22 \pm 4.4$ & $28.09 \pm 5.16$ & c 0.303 \\
\hline & Median (min-max) & $26.8(15.4-42.4)$ & $27.5(20.1-44.9)$ & \\
\hline \multirow{3}{*}{ Smoking history, n (\%) } & No & $56(16.5)$ & $4(13.3)$ & ' 0.374 \\
\hline & Ex-smoker & $168(49.6)$ & $12(40.0)$ & \\
\hline & Smoker & 115 (33.9) & $14(46.7)$ & \\
\hline \multirow{2}{*}{ CCI } & Mean \pm SD & $5.01 \pm 1.75$ & $5 \pm 1.49$ & ${ }^{\circ} 0.699$ \\
\hline & Median (min-max) & $5(0-11)$ & $5(2-8)$ & \\
\hline \multirow{3}{*}{ Symptom, n (\%) } & Asymptomatic & $30(8.8)$ & $0(0.0)$ & b0.240 \\
\hline & Macrohematuria & $278(82.0)$ & $27(90.0)$ & \\
\hline & LUTS & $31(9.1)$ & $3(10.0)$ & \\
\hline \multirow{3}{*}{ Tumor grade, n (\%) } & Low & $181(53.4)$ & $9(30.0)$ & ${ }^{\mathrm{b}} 0.026^{*}$ \\
\hline & Focal high & 37 (10.9) & $3(10.0)$ & \\
\hline & High & $121(35.7)$ & $18(60.0)$ & \\
\hline \multirow{2}{*}{$\begin{array}{l}\text { Number of tumors, } \mathbf{n} \\
(\%)\end{array}$} & Single & $181(53.4)$ & $17(56.7)$ & b0.730 \\
\hline & Multiple & $158(46.6)$ & $13(43.3)$ & \\
\hline \multirow{2}{*}{ Tumor diameter, n (\%) } & $<3 \mathrm{~cm}$ & $155(45.7)$ & $13(43.3)$ & ' 0.801 \\
\hline & $\geq 3 \mathrm{~cm}$ & $184(54.3)$ & $17(56.7)$ & \\
\hline \multirow{2}{*}{ T stage, n (\%) } & Ta & $225(66.4)$ & $10(33.3)$ & ${ }^{\mathrm{b}} 0.001^{* *}$ \\
\hline & $\mathrm{T} 1$ & $114(33.6)$ & $20(66.7)$ & \\
\hline \multirow{2}{*}{ Intravesical BCG, n (\%) } & BCG (-) & $229(67.6)$ & $19(63.3)$ & '0.637 \\
\hline & BCG (+) & 110 (32.4) & $11(36.7)$ & \\
\hline
\end{tabular}

patients according to their primary and secondary tumor histological grades and developed a combined score ranging from 2 to 6 . The authors concluded that a combined histological grade score provides more precise classification according to the prognosis of UCB. Furthermore, Billis et al. $^{10}$ investigated the relationship between tumor T stages in terms of combined histological grade scores and concluded that combined scores had statistically significant different $\mathrm{T}$ stages. Similarly, in our study, we found that high-grade tumors had more pT1 stage diseases than mixed and low-grade tumors and that mixed tumors had more pTl stage diseases than lowgrade tumors.

The most recent study on tumor heterogeneity was conducted in 2021. The authors evaluated the effect of tumor grade heterogeneity on recurrence rates in NMIBC. Mixed-grade patients were divided into two groups: patients with $\leq 5 \%$ and patients with $>5 \%$ high-grade components. This study included a total of 220 patients, with a median of two years of follow-up. Of these patients, $27(12 \%)$ had mixed-grade tumors. They concluded that there was no statistically significant difference among the four grade groups (pure low-grade, mixed with $\leq 5 \%$ high-grade component, mixed with $>5 \%$ high-grade component, and pure high-grade) in terms of RFS". This result is consistent with our finding that the RFS of our cohort was similar between the three histological grades $(\mathrm{p}=0.887$ ).

It is known that low- and high-grade UCB have different pathways of carcinogenesis. While low-grade 
carcinomas develop from the hyperplastic epithelium and have low rates of genetic alterations, high-grade carcinomas develop from dysplasia and have higher rates of genetic alterations $s^{12,13}$. The phenomenon of the presence of both low- and high-grade tumors in the same lesion could be explained by the activation of two different pathways of carcinogenesis in one bladder. In a study by Mai et al. ${ }^{14}$, the authors stated that some mixed-grade UCB that developed after previous low-grade carcinomas showed a more favorable prognosis than mixed-grade tumors that developed de novo.

There are limited studies investigating the clinical impact of mixed-grade tumors in mid- or long-term follow-up. A study including a total of 642 NMIBC patients reported no statistically significant difference between the three histological groups (low-, mixed-, or high-grade) in terms of RFS ( $\mathrm{p}=0.252)$. However, in this study, it was found that high-grade UCB had significantly worse PFS and CSS than low- or mixed-grade tumors and that mixed-grade UCB patients had PFS and CSS similar to patients with low-grade tumors ${ }^{7}$. Similarly, Reis et al. ${ }^{15}$ reported that mixed-grade UCB had a prognosis closer to low-grade UCB than high-grade UCB. Moreover, in a study investigating the BCG response rates of mixed-and high-grade tumors, Schubert et al. ${ }^{16}$ reported that mixedgrade tumors exhibit a significantly better response to BCG treatment than pure high-grade tumors.

In agreement with the aforementioned studies, we found that patients with mixed-grade tumors had RFS outcomes similar to patients with low- and highgrade tumors. According to our analysis, patients with mixed-grade tumors had worse PFS and CSS outcomes than patients with low-grade tumors $(199.84 \pm 23.22$ vs. $214.94 \pm 15.92$ for PFS and $202.07 \pm 19.86$ vs. $233.61 \pm 9.84$ for CSS, respectively) and better PFS and CSS outcomes than patients with high-grade tumors $(199.84 \pm 23.22$ vs. $163.28 \pm 16.18$ for PFS and $202.07 \pm 19.86$ vs. $180.81 \pm 15.89$ for CSS, respectively); however, these comparisons were not statistically significant. This result could be due to the relatively small number of patients with mixed-grade tumors or due to the inclusion of all patients with less than $25 \%$ high-grade components.

Our study has some limitations due to its retrospective design. We did not re-evaluate the pathological specimens. Our uropathologists report mixed-grade tumors as "focal high-grade areas in extensive low-grade tumor" routinely if the high-grade areas represent $\leq 25 \%$ of all tumors.
Therefore, we could not ascertain the exact percentage of the high-grade areas, which could potentially impact the oncological outcomes. In our study, low-grade histology was detected in $28(20.89 \%)$ patients and mixed-grade histology was detected in $17(12.68 \%)$ patients with pT1 tumors. Contrary to our study, some experts claim that all pT1 BTs should be considered as high-grade ${ }^{17}$. However, many recent studies report $\mathrm{pT1}$, low-grade patients in up to $28 \%{ }^{18}$. Our study was a single-center study with a relatively small sample of patients with mixed-grade tumors; therefore, our finding should be verified and validated by multicenter studies with larger sample size.

\section{CONCLUSION}

In this study, we demonstrated that tumor heterogeneity was detected in about $10 \%$ of our cohort of patients. Patients with mixed-grade tumors had significantly higher rates of pT1 stage diseases than patients with low-grade tumors and lower rates of pT1 stage diseases than patients with high-grade tumors. Patients with mixed-grade tumors had worse PFS and CSS outcomes than patients with low-grade tumors and better PFS and CSS outcomes than patients with highgrade tumors. However, these comparisons were not statistically significant. Our results should be verified and validated by future studies.

\section{Ethics}

Ethics Committee Approval: Following approval by the review board of Istanbul Medeniyet University Goztepe Training and Research Hospital (decision no: 2021/0280, date: 26.05.2021).

Informed Consent: Retrospective study.

Peer-review: Externally and internally peer-reviewed.

\section{Author Contributions}

Concept: M.C., Design: M.C., Data Collection and/or Processing: M.C., F.K., A.I., G.K., G.A., A.Y., Analysis and/ or Interpretation: M.C., F.K., A.I., G.K., G.A., A.Y., Critical revision: G.K., G.A., A.Y., Writing: M.C.

Conflict of Interest: The authors declare that they have no conflict of interest.

Financial Disclosure: The authors declared that this study has received no financial support.

\section{REFERENCES}

1. Siegel RL, Miller KD, Fuchs HE, Jemal A. Cancer Statistics, 2021. CA Cancer J Clin. 2021;71:7-33. Erratum in: CA Cancer J Clin. 2021;71:359. 
2. Burger M, Catto JWF, Dalbagni G, et al. Platinum priority - review bladder cancer epidemiology and risk factors of urothelial bladder cancer. Eur Urol. 2013;63:234-41.

3. Sylvester RJ, Rodríguez O, Hernández V, et al. European Association of Urology (EAU) Prognostic Factor Risk Groups for Non-muscleinvasive Bladder Cancer (NMIBC) Incorporating the WHO 2004/2016 and WHO 1973 Classification Systems for Grade: An Update from the EAU NMIBC Guidelines Panel[Formula present. Eur Urol. 2021;79:4808.

4. van der Kwast T, Liedberg F, Black PC, et al. International society of urological pathology expert opinion on grading of urothelial carcinoma. Eur Urol Focus. 2021. In press. doi: 10.1016/j.euf.2021.03.017

5. Eble J, Sauter G, Epstein J, Sesterhenn I. Pathology and genetics of tumours of the urinary system and male genital organs. Lyon, France: IARC Press; 2004

6. Babjuk M, Burger M, Compérat EM, et al. European Association of Urology Guidelines on non-muscle-invasive bladder cancer (TaT1 and Carcinoma In Situ) - 2019 Update. Eur Urol. 2019;76:639-57.

7. Gofrit ON, Pizov G, Shapiro A, et al. Mixed high and low grade bladder tumors - Are they clinically high or low grade? J Urol. 2014;191:1693-6.

8. Brierley JD, Gospodarowicz MD, Wittekind C, editors. TNM Classification of Malignant Tumours. 8th ed. New York: WileyBlackwell; 2017.

9. Cheng L, Neumann RM, Nehra A, Spotts BE, Weaver AL, Bostwick DG. Cancer heterogeneity and its biologic implications in the grading of urothelial carcinoma. J Urol. 2001;165:696-7.

10. Billis A, Carvalho RB, Mattos AC, et al. Tumor grade heterogeneity in urothelial bladder carcinoma: Proposal of a system using combined numbers. Scand J Urol Nephrol. 2001;35:275-9.
11. Ho P, Moran GW, Wang V, et al. The effect of tumor grade heterogeneity on recurrence in non-muscle invasive bladder cancer. Urol Oncol. 2021:S1078-1439(21)00304-5. doi: 10.1016/j.urolonc.2021.07.003. Epub ahead of print.

12. Castillo-Martin M, Domingo-Domenech J, Karni-Schmidt O, Matos T, Cordon-Cardo C. Molecular pathways of urothelial development and bladder tumorigenesis. Urol Oncol. 2010;28:401-8.

13. Cordon-Cardo C. Molecular alterations associated with bladder cancer initiation and progression. Scand J Urol Nephrol. 2008;42(Suppl 218):154-65.

14. Mai KT, Flood TA, Williams P, Kos Z, Belanger EC. Mixed low- and high-grade papillary urothelial carcinoma: Histopathogenetic and clinical significance. Virchows Archiv. 2013;463:575-81.

15. Reis LO, Taheri D, Chaux A, et al. Significance of a minor high-grade component in a low-grade noninvasive papillary urothelial carcinoma of bladder. Hum Pathol. 2016;47:20-5.

16. Schubert T, Danzig MR, Kotamarti S, et al. Mixed low- and high-grade non-muscle-invasive bladder cancer: a histological subtype with favorable outcome. World J Urol. 2015;33:847-52.

17. Compérat E, Varinot J, Moroch J, Eymerit-Morin C, Brimo F. A practical guide to bladder cancer pathology. Nat Rev Urol. 2018;15:143-54.

18. Grobet-Jeandin E, Wirth GJ, Benamran D, Dupont A, Tille JC, Iselin CE. Substaging of pT1 urothelial bladder carcinoma predicts tumor progression and overall survival. Urol Int. 2021:1-8. 